Western North American Naturalist 69(2), (C) 2009, pp. 260-263

\title{
CAPTURES OF CRAWFORD'S GRAY SHREWS (NOTIOSOREX CRAWFORDI) ALONG THE RIO GRANDE IN CENTRAL NEW MEXICO
}

\author{
Alice Chung-MacCoubrey ${ }^{1,2}$, Heather L. Bateman ${ }^{1,3}$, and Deborah M. Finch ${ }^{1}$
}

\begin{abstract}
We captured $>2000$ Crawford's gray shrews (Notiosorex crawfordi) in a riparian forest mainly consisting of cottonwoods (Populus deltoides) along the Rio Grande in central New Mexico. Little has been published about abundance and habitat of Crawford's gray shrew throughout its distributional range. During 7 summers, we captured shrews in pitfall traps at 13 study sites in Bernalillo, Valencia, and Socorro counties. Capture rates of shrews were greatest in August and September, and we did not detect a response of shrews to restoration treatments that removed nonnative plants from riparian forests. Results from our study indicate that (1) Crawford's gray shrews are more abundant in riparian habitats than historically presumed and (2) pitfall traps with drift fences are an effective means to capture shrews.
\end{abstract}

Key words: Notiosorex crawfordi, capture rate, riparian areas, pitfall traps, New Mexico, Rio Grande.

Crawford's gray shrews (Notiosorex crawfordi) occur in the southwestern United States as well as in northern and central Mexico (Hutterer 2005). Crawford's gray shrews inhabit various arid habitats and are commonly reported in upland desert scrub (Armstrong and Jones 1972). A few recent records in Arizona, however, describe $N$. crawfordi occurring in cottonwood-willow (Populus-Salix sp.) habitats (Duncan and Corman 1991) and in riparian woodlands with oak (Quercus sp.) and sycamore (Platanus wrightii; Carothers 1968). In New Mexico, little information has been published regarding the relative abundance or habitat associations of Crawford's gray shrews. Findley et al. (1975) reported $N$. crawfordi in various habitats only from 8 scattered localities throughout the state. In the Rio Grande valley, Bailey (1931) reported that $N$. crawfordi occurs in the area, and Hink and Ohmart (1984) captured 49 individuals in pitfall traps along the Rio Grande between the Jemez River and Rio Puerco. Hink and Ohmart (1984) suggested that populations of this species exist along the Rio Grande but did not provide much detail on habitat and distribution.

As part of a study designed to evaluate the effects of nonnative plant and fuels removal on wildlife, we monitored herpetofauna for 7 years in central New Mexico (Bateman et al. 2008a, 2008b). During our study, we frequently captured Crawford's gray shrews in pitfall traps. This provided an opportunity to document the relative abundance of $N$. crawfordi along the Rio Grande in central parts of the state and to determine whether removal of nonnative vegetation affected capture rates of this species of shrew.

We established trapping arrays in thirteen 20-ha sites in 3 geographic regions (north, middle, and south) near Albuquerque (35 $\left.00^{\prime} 04^{\prime \prime} \mathrm{N}, 106^{\circ} 41^{\prime} 04^{\prime \prime} \mathrm{W}\right)$, Bernalillo County; near Los Lunas $\left(34^{\circ} 50^{\prime} 39^{\prime \prime} \mathrm{N}, 106^{\circ} 42^{\prime} 44^{\prime \prime} \mathrm{W}\right)$, Valencia County; and at the Bosque del Apache National Wildlife Refuge $\left(33^{\circ} 47^{\prime} 59^{\prime \prime} \mathrm{N}\right.$, $\left.106^{\circ} 52^{\prime} 59^{\prime \prime} \mathrm{W}\right)$, Socorro County. Sites were in riparian forests containing a mixture of native Rio Grande cottonwood (Populus deltoides wislizenii) and nonnative plants, including saltcedar (Tamarix chinensis and Tamarix ramosissima) and Russian olive (Elaeagnus angustifolia). Our study design required 12 study sites, and a 13th site was added to replace one that burned in a wildfire in 2001 . Thus, we monitored 11 sites annually from 2000 to 2006 , and we monitored the burned site from 2000 to 2004 and its replacement from 2002 to 2006. Nonnative plants and fuels were removed from 9 experimental sites; the 4 other sites lacking removal of nonnative species were control sites. The experimental treatment included removal of nonnative

${ }^{1}$ USDA Forest Service, Rocky Mountain Research Station, 333 Broadway SE, Suite 115, Albuquerque, NM 87102

${ }^{2}$ Present address: USDI National Park Service, Mojave Desert Network, 601 Nevada Highway, Boulder City, NV 89005.

${ }^{3}$ Corresponding author. Present address: Arizona State University Polytechnic, Department of Applied Biological Sciences, 6073 S. Backus Mall, Suite 340L, Mesa, AZ 85212. E-mail: heather.bateman@gmail.com 
plants by cutting with chainsaws, burning slash piles, and planting native shrubs. Experimental treatments began in 2003, were completed in 2005 , and were performed during autumn or winter to reduce disturbance to terrestrial vertebrates. We measured vegetation in control and experimental sites before and after treatment along 50-m transects and in 4m-radius plots (see Bateman et al. 2008a for details).

We used methods designed to capture herpetofauna primarily, and captures of mammals were incidental. A trap array consisted of 3 drift fences, 6 pitfalls (18.9 liter buckets) with cover boards, and 6 funnel traps (about $15 \times$ $60 \mathrm{~cm})$. We established 3 trap arrays in each site at a random distance $>25 \mathrm{~m}$ from the edge of each site and >320 m apart. Each 6$\mathrm{m}$-long fence began $7.5 \mathrm{~m}$ from a central point and was positioned at $0^{\circ}, 120^{\circ}$, and $240^{\circ}$ (see Bateman et al. 2008a). We checked traps every 2-4 days, and traps were open continuously from June to mid-September every year except in 2000, during which trapping occurred from June to early August.

We defined capture rate as the number of shrews caught per 100 trap-days per site. A trap-day was defined as one day during which all traps were open at an array, which included 6 pitfalls and 6 funnel traps. Captures were combined among the 3 arrays at a site (e.g., 3 arrays open for 10 days $=30$ trap-days per site). Live shrews were released unmarked, and it is possible that we captured some individuals multiple times. Shrews that died in traps were kept as voucher specimens and deposited in the Museum of Southwestern Biology (MSB), University of New Mexico, Albuquerque (catalog numbers MSB 125426-125559).

We used a repeated-measures ANOVA with years as a repeated effect (SPSS, Inc., version 13.0, Chicago, IL; mixed procedure with 1storder autoregressive correlation among years) to test for treatment effect on capture rate of shrews. Capture rate was transformed using an $\ln (x+1)$ transformation to meet the normality assumption. We tested for effects of region (north, middle, and south), period (preand posttreatment), and assigned treatment (control and experimental sites). We defined pretreatment years as 2000-2002 and posttreatment years as 2003-2006 for all sites except 2 in which the experimental treatment was applied in 2004 and 2005. Therefore, we defined posttreatment years as 2004-2006 for one site and 2005-2006 for the second site. We used 12 sites in the analysis by omitting the control site that burned at the beginning of the study and including its replacement site for later years.

During 7 years, we captured 12 species of small mammals. Crawford's gray shrews were the most abundant mammal captured in pitfalls, amounting to 2146 captures. Other captures included 592 Peromyscus (white-footed mouse Peromyscus leucopus and deer mouse Peromyscus maniculatus), 31 Perognathus (silky pocket mouse Perognathus flavus and Plains pocket mouse Perognathus flavescens), and 31 Mus musculus (house mouse). Some shrews were placed in a cloth bag of known mass and weighed with a Pesola scale. Average mass of shrews was $3.5 \mathrm{~g}(s=0.04, n=263)$.

Capture rates of shrews were greatest in August and September compared to earlier summer months, and capture rates varied among years (Table 1). Mean capture rate of shrews was greater in the north region $(15.9, s$ $=1.8)$ than in the middle $(5.4, s=0.6)$ and south regions $\left(6.6, s=0.8 ; F_{2,19.7}=17.1, P\right.$ $<0.001)$. Mean capture rate was greater in experimental sites $(9.9, s=0.9)$ compared to control sites $\left(7.5, s=2.1 ; F_{1,21.1}=7.8, P=\right.$ $0.011)$; however, there was no effect of pretreatment versus posttreatment $\left(F_{1,39.3}=0.3\right.$, $P=0.574)$. In that analysis, a treatment effect would have been indicated by a significant period (pre- vs. posttreatment) $\times$ group $($ control vs. experimental site) interaction. We did not detect a significant period $\times$ group interaction $\left(F_{1,40.3}=1.5, P=0.232\right)$, and thus, we did not detect a difference in capture rates of shrews at sites with and without removal of nonnative plants and fuels.

We captured all shrews in pitfalls and none in funnel traps in a riparian cottonwood forest. Other species of trees and shrubs in the understory included the nonnative plants saltcedar and Russian olive, and native plants such as Goodding's willow (Salix gooddingii), coyote willow (Salix exigua), and seep willow (Baccharis salicifolia). Sites with damp soil contained the perennial herb yerba mansa (Anemopsis californica). Characteristics of canopy cover and density of cottonwood trees were similar in control and experimental sites and did not vary over time between pretreatment and posttreatment conditions (Bateman 
TABLE 1. Total number of Crawford's gray shrews (Notiosorex crawfordi) captured per month and mean capture rate ( \pm standard deviation) along the Rio Grande in central New Mexico. Shrews were captured in pitfalls in trapping arrays intended for sampling herpetofauna. Capture rate is the number of shrews caught per 100 trap days per site. In 2000 the trapping period was shorter than in subsequent years.

\begin{tabular}{lcccccccc}
\hline Month & 2000 & 2001 & 2002 & 2003 & 2004 & 2005 & 2006 & Capture rate \\
\hline June & 12 & 42 & 11 & 45 & 32 & 81 & 37 & $4.7 \pm 4.8$ \\
July & 51 & 107 & 163 & 46 & 44 & 79 & 52 & $7.5 \pm 7.0$ \\
August & 2 & 174 & 151 & 96 & 84 & 225 & 91 & $10.5 \pm 12.2$ \\
September & - & 161 & 120 & 81 & 53 & 93 & 13 & $15.2 \pm 15.1$ \\
Capture rate & $3.4 \pm 1.5$ & $13.4 \pm 8.9$ & $12.4 \pm 8.1$ & $7.7 \pm 5.7$ & $6.8 \pm 6.1$ & $13.8 \pm 11.3$ & $6.5 \pm 3.0$ & \\
\hline
\end{tabular}

et al. 2008a). In contrast, large woody debris and nonnative plants were reduced after experimental treatments (see Bateman et al. 2008a). Canopy cover ranged from $81.9 \%$ to $87.7 \%$, cottonwood basal area ranged from 14.1 to $21.9 \mathrm{~m}^{2} \cdot \mathrm{ha}^{-1}$, and depth of ground litter ranged from 3.5 to $4.8 \mathrm{~cm}$. The experimental treatments reduced numbers of nonnative plants (saltcedar and Russian olive) and numbers of branches and logs on the ground. The percent of ground covered by wood chips and small sticks increased from $0 \%$ to $14.7 \%$ after experimental treatments. During the period of study, percent of ground covered by forbs and grass ranged from $17.2 \%$ to $54.0 \%$. Generally, the riparian forest was dry and not inundated with surface or groundwater; however, 2 sites flooded in spring 2005 (Bateman et al. 2008b). At least one shrew was captured in every type of microhabitat and pitfall trap during the study.

Distributional information is relatively limited for $N$. crawfordi, as are data on habitat associations. Armstrong and Jones (1972) reported that Crawford's gray shrews primarily were associated with semidesert scrub in uplands and were occasionally discovered in riparian habitats. Yet, additional evidence suggests that Crawford's grey shrew is more commonly associated with riparian habitats than originally reported. In our study, large numbers of Crawford's gray shrews were captured in native cottonwood forest with a mixed understory of nonnative vegetation and native willows. Most shrews captured by Hink and Ohmart (1984) were from riparian sites with dense thickets of coyote willow along the Middle Rio Grande. Similarly, along the San Pedro River in Arizona, the greatest abundance of Crawford's gray shrews occurred in riparian cottonwood-willow habitat (Populus fremontiiSalix spp.), exceeding abundances in upland sites (Duncan and Corman 1991).
Increased capture rates of shrews in late summer following monsoonal rains may reflect increased population size, increased activity, or both. In the southwestern United States, rodents usually increase in abundance during or following rainfall (Brown and Heske 1990, Ernest et al. 2000, Morrison et al. 2002). Central New Mexico typically experiences monsoonal rains during July and August, but rainfall varies considerably among years (NOAA 2000-2006; Los Lunas, Valencia County, www.noaa.gov). Greater capture rates of shrews in August and September may reflect reproduction following summer monsoons or shrews becoming more active during conditions favorable for prey and other resources. Duncan and Corman (1991) also reported high shrew abundances in summer compared to shrew abundances in nonreproductive seasons in Arizona.

Capture rates of shrews were not affected by the treatment to remove nonnative plants and fuels. Treatment effects may have been difficult to detect due to large variations in captures among years and study blocks. Alternatively, the treatment effect may not have significantly affected habitat or resources of shrews, or perhaps shrews were plastic to a range of conditions (e.g., prey and cover).

Methods used to sample shrews may influence capture success and, consequently, perceptions of their abundance. Findley et al. (1975) suggested that Crawford's gray shrews are likely more common than capture records indicate, and perhaps this disparity is related to methods of data collection. Pitfalls may be more efficient at sampling abundance of shrews (Brown 1967, Williams and Braun 1983, Bury and Corn 1987, Mengak and Guynn 1987, McCay and Komoroski 2004) than snap traps or live traps, because shrews appear to avoid live traps (Kirkland and Sheppard 1994). Our study also demonstrated that pitfalls were 
highly effective at capturing shrews. Snap traps and live traps are more commonly used to capture small mammals than pitfalls are; thus, shrews are likely underrepresented in many studies. Sampling methods should be considered when researchers interpret and compare results among studies with shrews, and a standard protocol for sampling shrews should include a combination of pitfalls and drift fences (Kirkland and Sheppard 1994).

We thank the Middle Rio Grande Conservancy District, Bosque del Apache National Wildlife Refuge, and Albuquerque Open Space for permitting access to study sites. We thank Dave Hawksworth (Rocky Mountain Research Station [RMRS]) and numerous RMRS field assistants for collecting and processing data. We also thank Cindy Ramotnik (Museum of Southwestern Biology) for museum matters associated with voucher specimens. The University of New Mexico Animal Care and Use Committee approved field techniques (protocol \#20415). This study was funded by the USDA Forest Service - RMRS Middle Rio Grande Ecosystem Management Unit, Joint Fire Sciences Program, National Fire Plan; U.S. Fish and Wildlife Service Middle Rio Grande Bosque Initiative; and USDA Forest Service State and Private Forestry New Mexico Collaborative Forest Restoration Program. Additional support to Heather Bateman was provided by University of New Mexico (UNM) Graduate Research Development grants, UNM Grove grants, and a National Fish and Wildlife Foundation grant. We thank 2 anonymous reviewers for helpful comments and suggestions.

\section{Literature Cited}

Armstrong, D.M., And J.K. Jones, JR. 1972. Notiosorex crawfordi. Mammalian Species 17:1-5.

Bailey, V. 1931. Mammals of New Mexico. United States Department of Agriculture, Bureau of Biological Survey, Washington, DC. 412 pp.

Bateman, H.L., A. Chung-MacCoubrey, and H.L. Snell. 2008a. Impact of non-native plant removal on lizards in riparian habitats in the Southwestern U.S.A. Restoration Ecology 16:180-190.

Bateman, H.L., M.J. Harner, and A. Chung-MaCCoubrey. 2008b. Abundance and reproduction of toads (Bufo) along a regulated river in the southwestern United States: importance of flooding in riparian ecosystems. Journal of Arid Environments 72:1613-1619.
Brown, J.H., And E.J. Heske. 1990. Temporal changes in a Chihuahuan Desert rodent community. Oikos 59:290-302.

Brown, L.N. 1967. Ecological distribution of 6 species of shrews and comparison of sampling methods in the central Rocky Mountains. Journal of Mammalogy 48:617-623.

Bury, R.B., AND P.S. CORN. 1987. Evaluation of pitfall trapping in northwestern forests: trap arrays with drift fences. Journal of Wildlife Management 51:112-119.

Carothers, S.W. 1968. Additional records of Notiosorex c. crawfordi in Arizona. Southwestern Naturalist 13:449.

Duncan, D.K., and T.E. Corman. 1991. Relative abundance of desert shrews (Notiosorex crawfordi) within the San Pedro Riparian National Conservation Area, Arizona. Southwestern Naturalist 36:119-121.

Ernest, S.K.M., J.H. Brown, And R.R. Parmenter. 2000. Rodents, plants, and precipitation: spatial and temporal dynamics of consumers and resources. Oikos 88:470-482.

Findley, J.S., A.H. Harris, D.E. Wilson, and C. Jones. 1975. Mammals of New Mexico. University of New Mexico Press, Albuquerque, NM. 360 pp.

Hink, V.C., And R.D. Ohmart. 1984. Middle Rio Grande biological survey. Final report to the U.S. Army Corps of Engineers No. DACW47-81-C-0015. Center for Environmental Studies, Arizona State University, Tempe. 193 pp.

Hutterer, R. 2005. Order Soricomorpha. Pages 220-311 in D.E. Wilson and D.M. Reeder, editors, Mammal species of the world: a taxonomic and geographic reference. Johns Hopkins University Press, Baltimore, MD.

Kirkland, G.L., JR., And P.K. Sheppard. 1994. Proposed standard protocol for sampling small mammal communities. Pages 277-283 in J.F. Merritt, G.L. Kirkland, Jr., and R.K. Rose, editors, Advances in the biology of shrews. Carnegie Museum of Natural History Special Publication No. 18, Carnegie Museum of Natural History, Pittsburgh, PA.

MCCaY, T.S., AND M.J. KomorosKi. 2004. Demographic responses of shrews to removal of coarse woody debris in a managed pine forest. Forest Ecology and Management 189:387-395.

MengaK, M.T., and D.C. Guynn, Jr. 1987. Pitfalls and snap traps for sampling small mammals and herpetofauna. American Midland Naturalist 118:284-288.

Morrison, M.L., A.J. Kuenzi, C.F. Brown, And D.E. SWANn. 2002. Habitat use and abundance trends of rodents in southeastern Arizona. Southwestern Naturalist 47:519-526.

[NOAA] National Oceanic and Atmospheric AdminisTRATION. 2000-2006. Monthly total precipitation from Los Lunas, NM (station \#295150) [accessed 12 December 2006]. Available from: http://www.wrcc .dri.edu/cgi- bin/cliMONtpre.pl?nm5150

Williams, D.F., and S.E. Braun. 1983. Comparison of pitfall and conventional traps for sampling small mammal populations. Journal of Wildlife Management 47:841-845.

Received 21 April 2008 Accepted 28 October 2008 